Laboratory of Neuropathology, Department of Psychiatry, University of Michigan, Medical Center, Ann Arbor, Michigan

\title{
THE STRUCTURES OF THE GLIA AND OF THE SYNAPSES IN THE SYMPATHETIC CHAIN OF MAN
}

\section{(A STUDY WITH SILVER CARBONATE) \\ By}

\section{K. ScharenBerg*}

With 30 Figures in the Text

(Received November 24, 1959)

The morphology of the glia of the sympathetic and of the spinal ganglia was investigated with the silver carbonate method by DEL Rro HoRTEGA and his associates Prado and Polak (1942). Scharenberg (1953) described the glia of

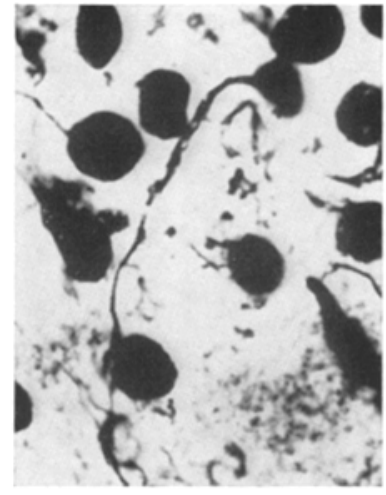

Fig. 1

Fig. 1. Group of predominately monopolar interconnected perisomatic gliocytes. Polar View $\times 1000$

Fig. 2. Monopolar gliocyte with an ova1 body and one very long, gently arched, thin process. Equatorial View $\times 1200$

Fig. 3. Gliocyte with an oval body and one strong process. $\times 1200$
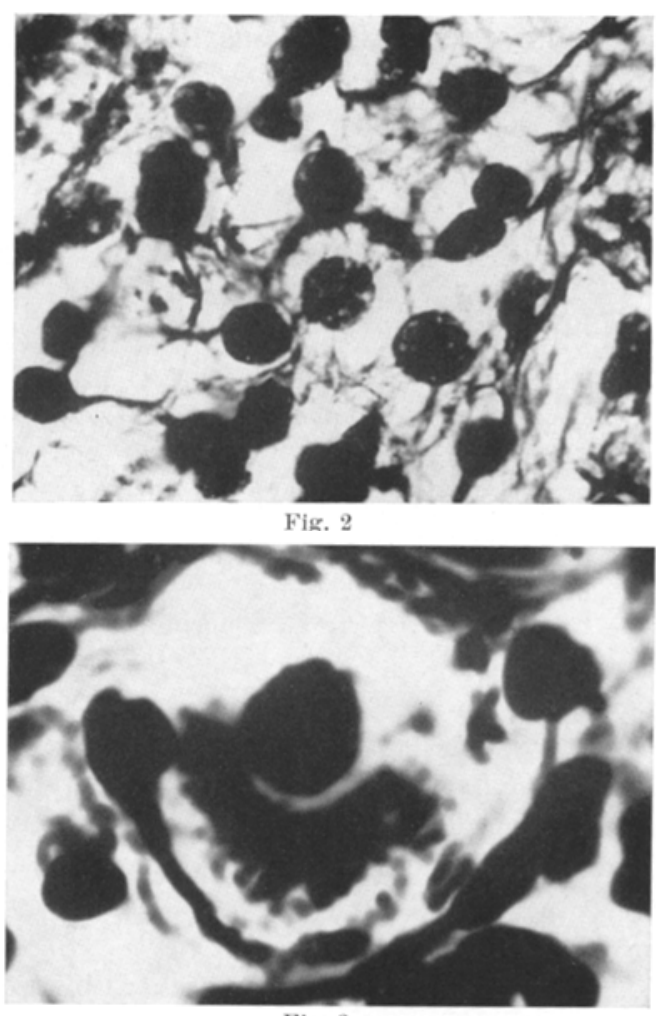

Fig. 3

the Gasserian ganglion, and OrTiz-Picon (1955) that of the spinal ganglia. Both authors confirmed the findings of DeL Rio Hortega. Hortega's work in the sympathetic chain has, so far, not been confirmed because the impregnation of

\footnotetext{
* Supported by grant in aid B-418 C5 U.S. Department of public health.
} 
the glia of the authonomous nervous system is difficult and requires careful adjustment of the technique. This contribution is carried out with the silver carbonate technique and is documented by un-retouched microphotographs. Human tissue was used exclusively.

Des Rio Hortega designated the glia of the sympathetic chain and of the spinal ganglia as gliocytes and distinguished two types: 1. The perisomatic and, 2. periexpansional or periaxonic elements. 1. The perisomatic glia surround

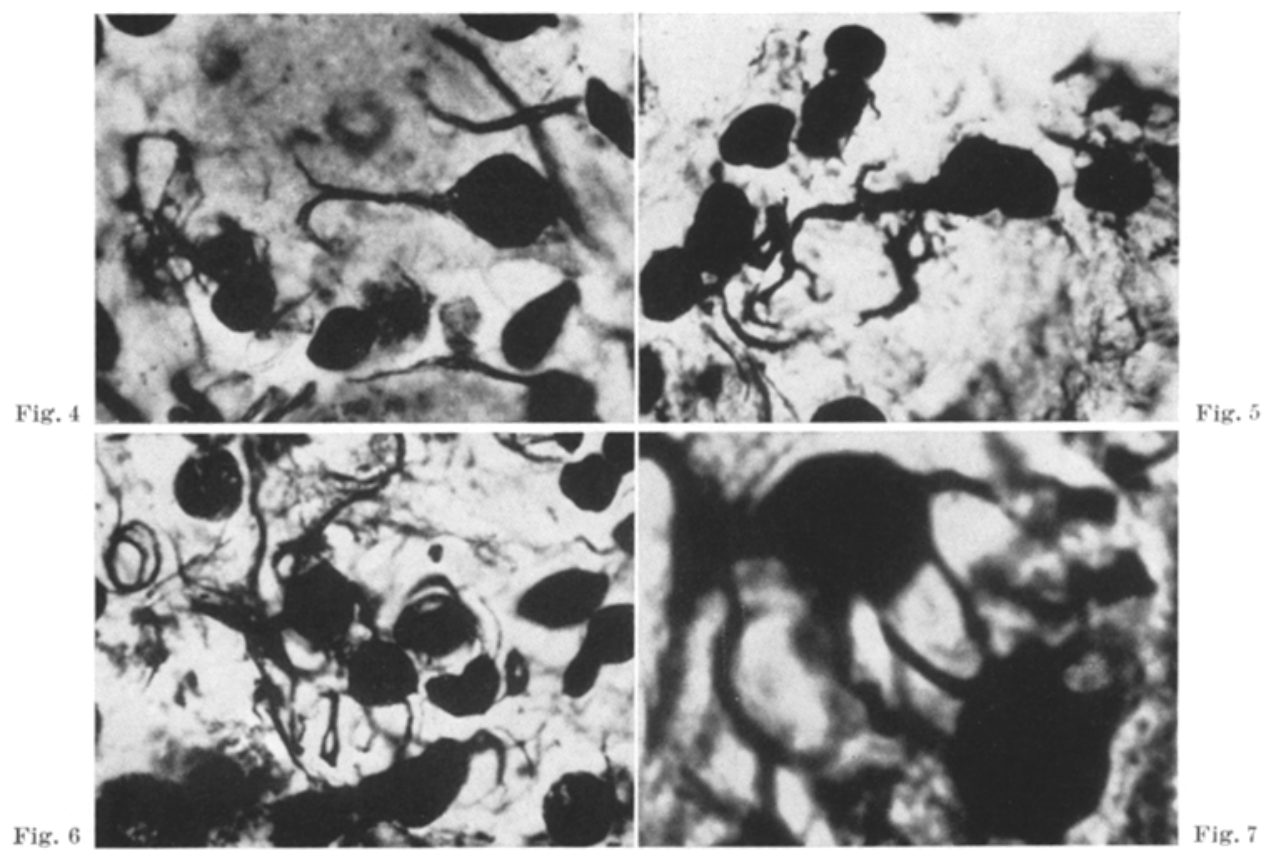

Fig. 4. Monopolar gliocyte with an arched process. Equatorial View $\times 1200$

Fig. 5. Dichotomized perisomatic gliocyte with round body. $\times 1200$

Fig. 6. Gliocytes of various types; some with coiled processes

Fig. 7. Interconnected multipolar gliocytes. Polar View $\times 1200$

the pericarion of the neuron with a network of cells in which two different layers can be distinguished: a) polymorph cells which form the upper layer, and b) the laminar elements which lay on the pericarion. 2. The periexpansional or periaxonic and peridendritic elements, which HorTega called spirocytes, surround the axons and dendrites with coiled processes. These cells are restricted to the proximal segment of the axons and dendrites which are enclosed in a connective tissue capsule.

1. The perisomatic glia is represented by morphologically very different types of cells: there are numerous mono-bi- and pluripolar elements with round or oval bodies and straight or gently arched processes; these cells frequently form a network of interlaceing plasmatic bridges which enclose the pericarion (Fig. 1-7). A different type of gliocyte is represented by elements with ring-like processes or with short spirals ("handle cells" of HorTeGa) (Fig. 8-11). As a rule the gliocytes are more strongly impregnated than the neurons and appear elearly 
outlined; the pericaryon is usually lightly stained, or not stained at all; this is desirable in order to visualize the glia. Occasionally the impregnation of both the neuron and the glia is so well balanced as to demonstrate the relationship between the gliocytes and the pericaryon (Fig. 12). Two different types of elements can

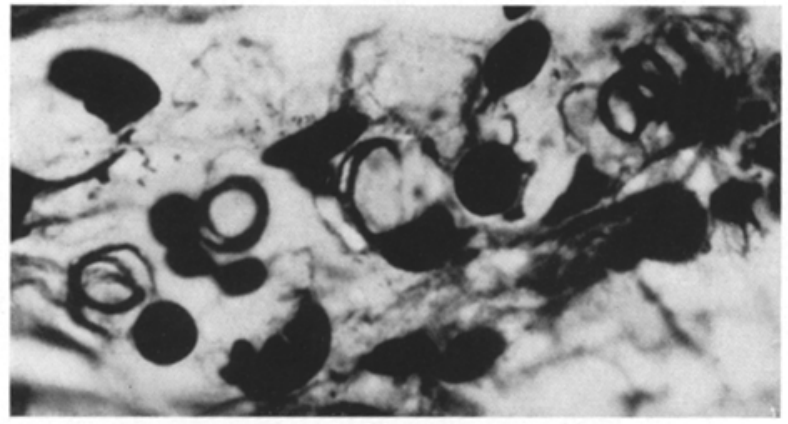

be recognized in this illustration: one cell with an oval body and a single coiled process is a perisomatic gliocyte (a); the other with an elongated body and a gently arched process which lays on the pericaryon (b) represents the central process of the spirocyte.
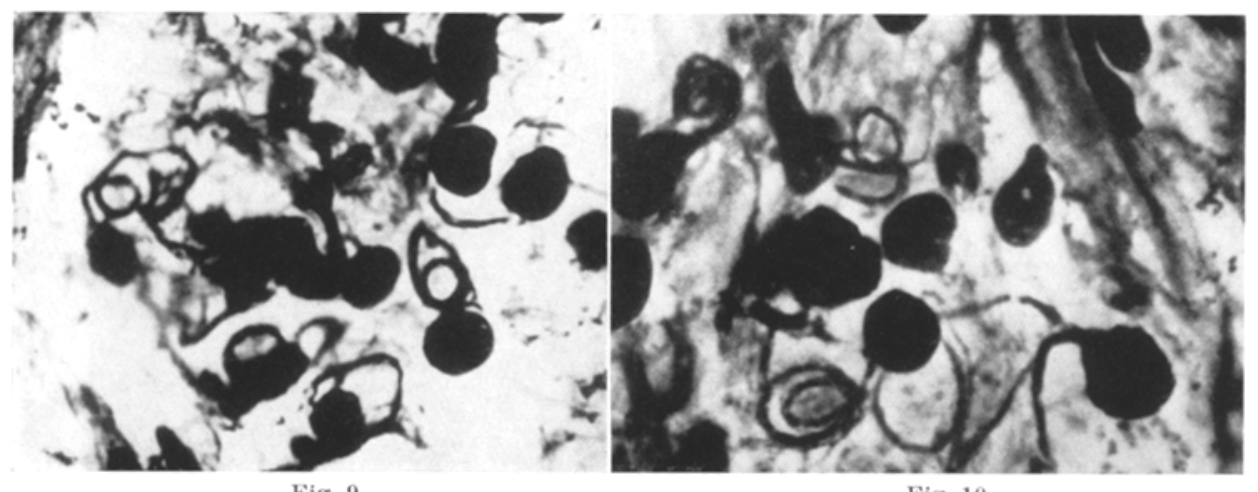

Fig. 8. Perisomatic gliocytes with a single ring-like process (handle cell of HoRTeGa) Other cells have several coiled or arched processes. Polar View $\times \mathbf{1 2 0 0}$

Fig. 9. Several gliocytes of the "handle cell type". $\times 1200$

Fig. 10. Gliocytes with predominantly arched processes, some have coiled processes. $\times 1200$

Fig. 11. Gliocyte with numerous interconnected processes of a complicated pattern

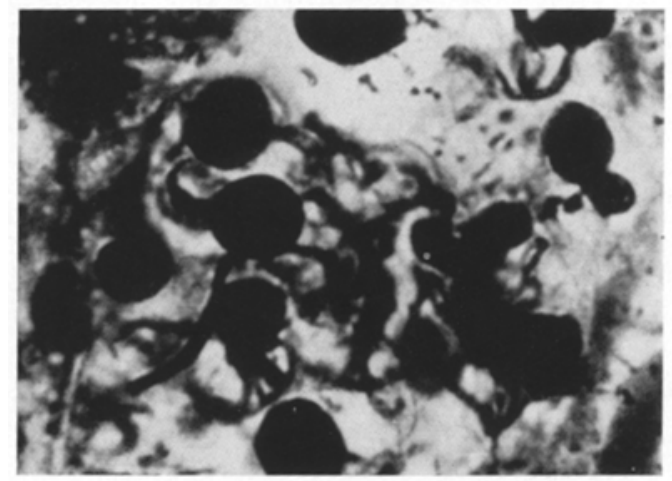

Fig. 11

The laminar perisomatic gliocytes: these elements have a round nucleus and a very large "reticular" or vacuolated cytoplasm of a very irregular shape which covers the entire pericaryon (HoRTEGA) (Fig. 13-15).

2. The periexpansional (periaxonic and peridendritic) spirocytes surround the large processes of the neurons with their coils which give these elements a characteristic appearance. In general four types of spirocytes can be distinguished 
although there are several transitional forms : a) elements with long, widely spaced coils, b) with compact coils, c) with intertwined coils and d) mixed types (HoRTEGA).

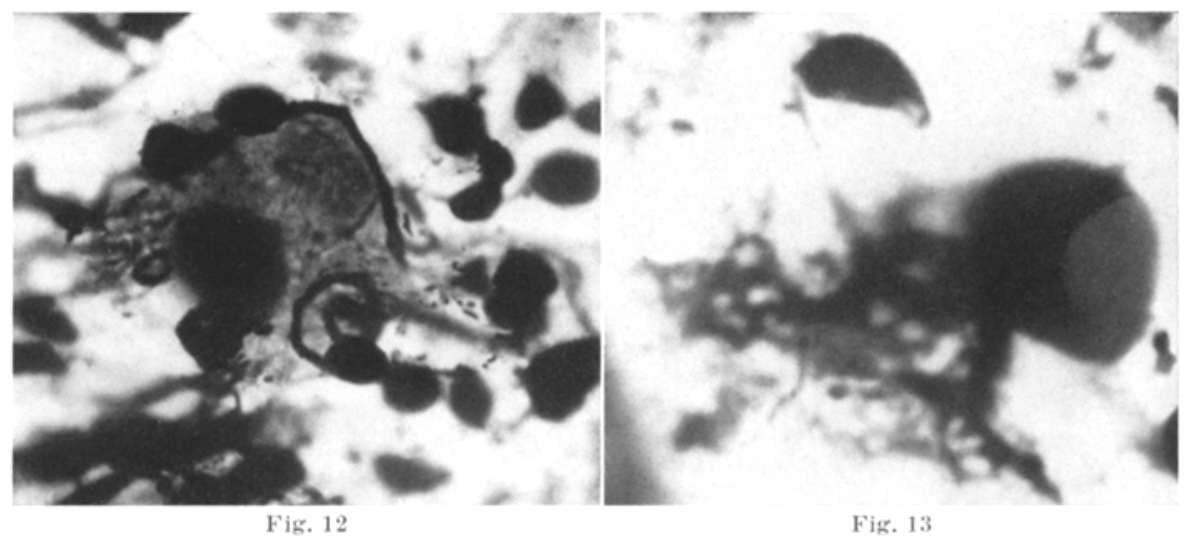

Fig. 12. Pexicaryon of a neuron with a coiled process of a gliocyte and central process of a spirocyte

Fig. 13. Laminar glioeyte with a round pericaryon and a large eloud-like vacuolated eytoplasm. $\times 2000$

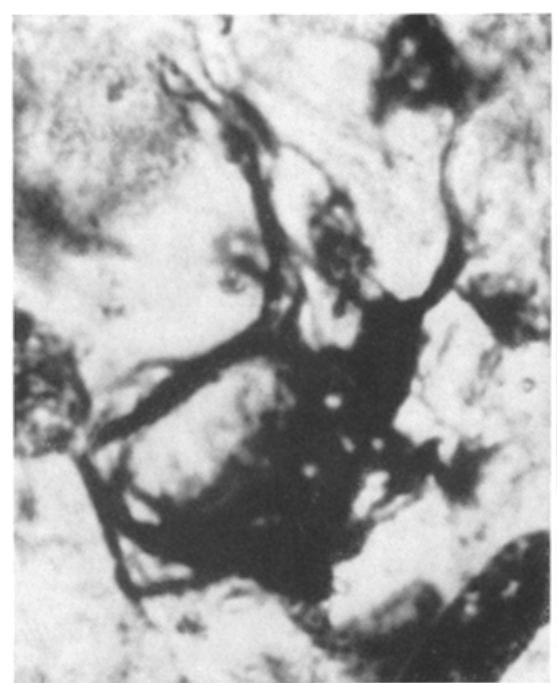

Fig. 14

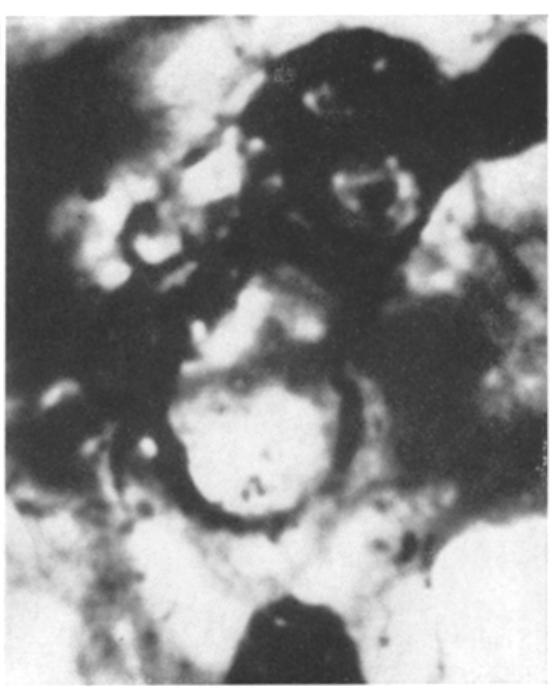

Fig. 15

Fig. 14. Laminar element with a very large codrsely vacuolated eytoplasm. $\times 2000$

Fig. 15. Laminar glioeyte of a very irregular shape with one very large and several small vacuoles and long processes

a) The long spirocytes have an oval body which is placed near the axon, but not on it; their coiled processes are widely spaced. HoRTEGA noted that there is a seemingly "empty space" between the coils and the axon (Fig. 16-19). The significance of this phenomenon will be discussed later. Several spirocytes support a single axon. Fig. 17 shows twelve coils of two spirocytes; Hortega found as many as four spirocytes with twenty spirals. Although the spirocytes are 
primarily periexpansional elements they, nevertheless, have a central process which originates from the body of the cell and connects the spirocyte with the pericaryon of the neuron (Fig. 12 and 18).

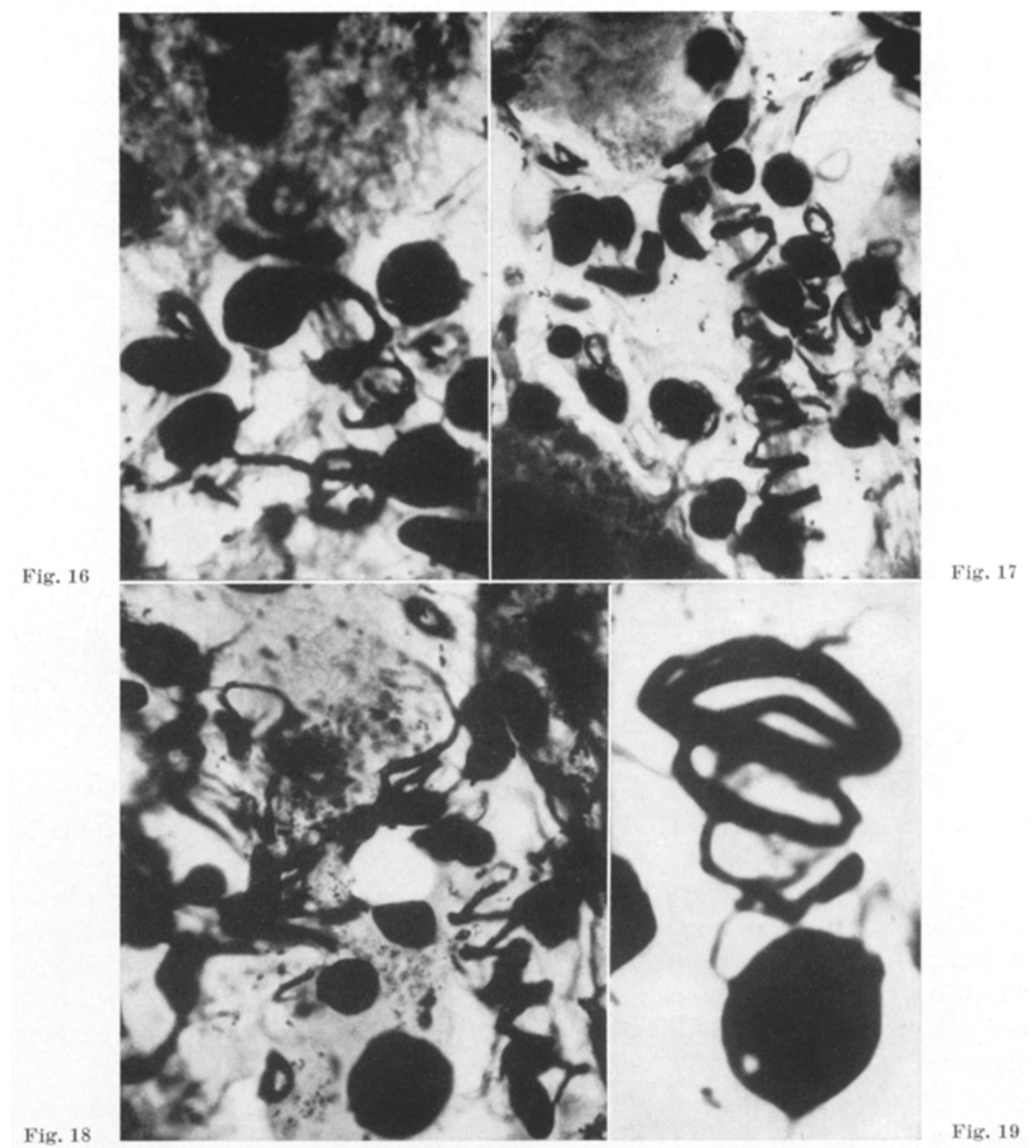

Fig. 16. Spirocyte with an oval body which is placed near the neurite; several coils surround the neurite; there is a distinct "empty space" between the coils and the neurite. $\times 2000$

Fig. 17. The neurite is surrounded by 12 coils of two spirocytes. In the right upper part of the picture there are two more spirocytes. $\times 2000$

Fig. 18. Spirocyte with widely spaced coils and a central process which lays on the pericaryon of the neuron. $\times 2000$

Fig. 19. Spirocyte with a round body and very wide coils. $\times 2000$

b) Spirocytes with closely wound spirals: the coils of this variety are thicker and are more compact than of the above described type, but they also leave an "empty space" between them and the axon (Fig. 20). 
c) Spirocytes with double or intertwined coils which represent the processes of two elements (Fig. 21).

d) Spirocytes of transitional or mixed type are elements with a large, bulky, oval or round, pericaryon, and with processes which resemble massive rings, which are either directly connected with the body of the cell or by a short stubby process (Fig. 22). To the same variety belong also elements with a single massive process and several spirals (Fig. 23). A strong process connects this type of spirocyte with other perisomatic elements.

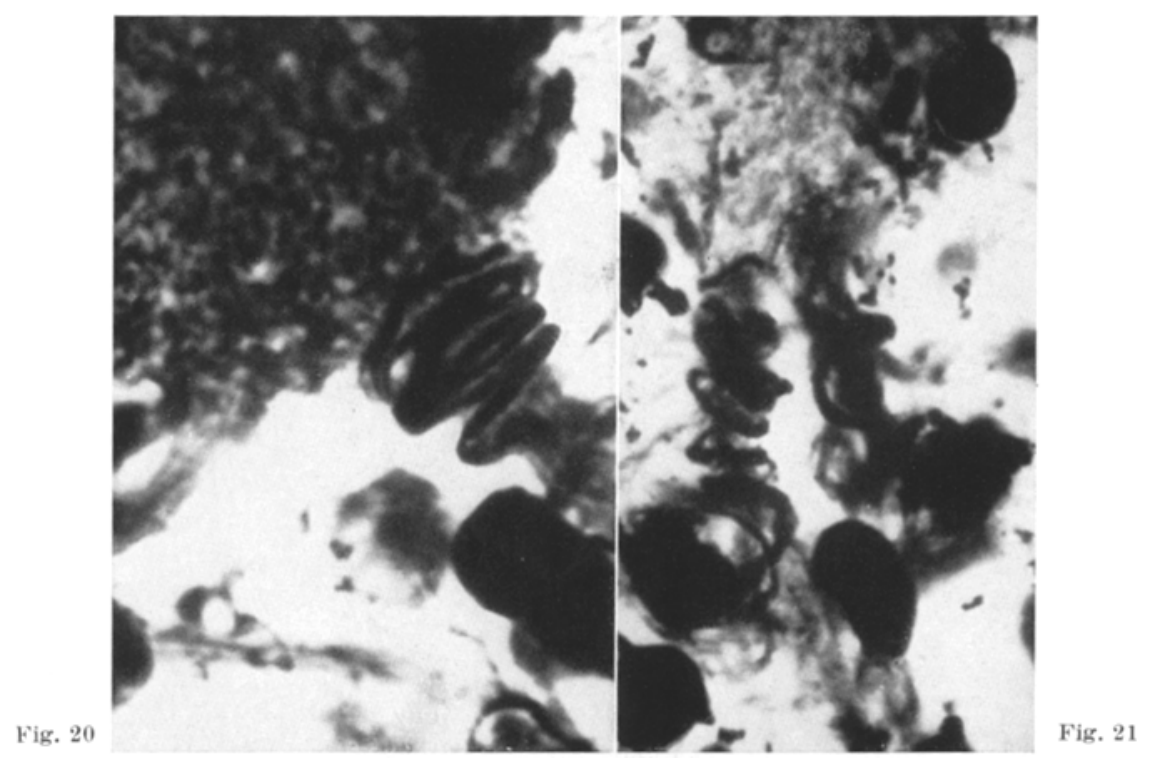

Fig. 20. Spirocyte with compact cells. $\times 2000$ Fig. 21 . Two spirocytes with intertwined coils. $\times 12000$

Summary. The auxiliary system of glia of the neurons of the sympathetic chain consists of two component parts: 1. The perisomatic network which surrounds the pericaryon and consists of two layers of cells : a) the laminar elements which lay very close to the pericaryon and form the inner layer, and b) the interlacing layer of mono-bi- and pluripolar gliocytes which is spread over the laminar elements.

2. The periexpansional glia or spirocytes are of four types: a) long spirocytes with widely spaced coils, b) with compact coils, c) With intertwined coils and d) mixed types.

\section{Classification of the Gliocytes}

In the sympathetic chain and in the gasserian and spinal ganglia there is the same intimate relationship between the neurons and their satellite cells as there is between the astrocytes, the oligodendroglia and the parenchyma cells in the brain. It is, therefore, obvious that the perisomatic and the periexpansional gliocytes of the peripheral nervous system must be regarded as glia and their classification can be based on principles accepted for the glia of the central nervous system (Hortega and Prado). 
According to Del Rio Hortega and OrTiz-Picon the periexpansional glia, i.e. the spirocytes are homologous with the oligodendroglia of type III (PALLADINO) which they closely resemble: the body of the spirocyte is placed near the

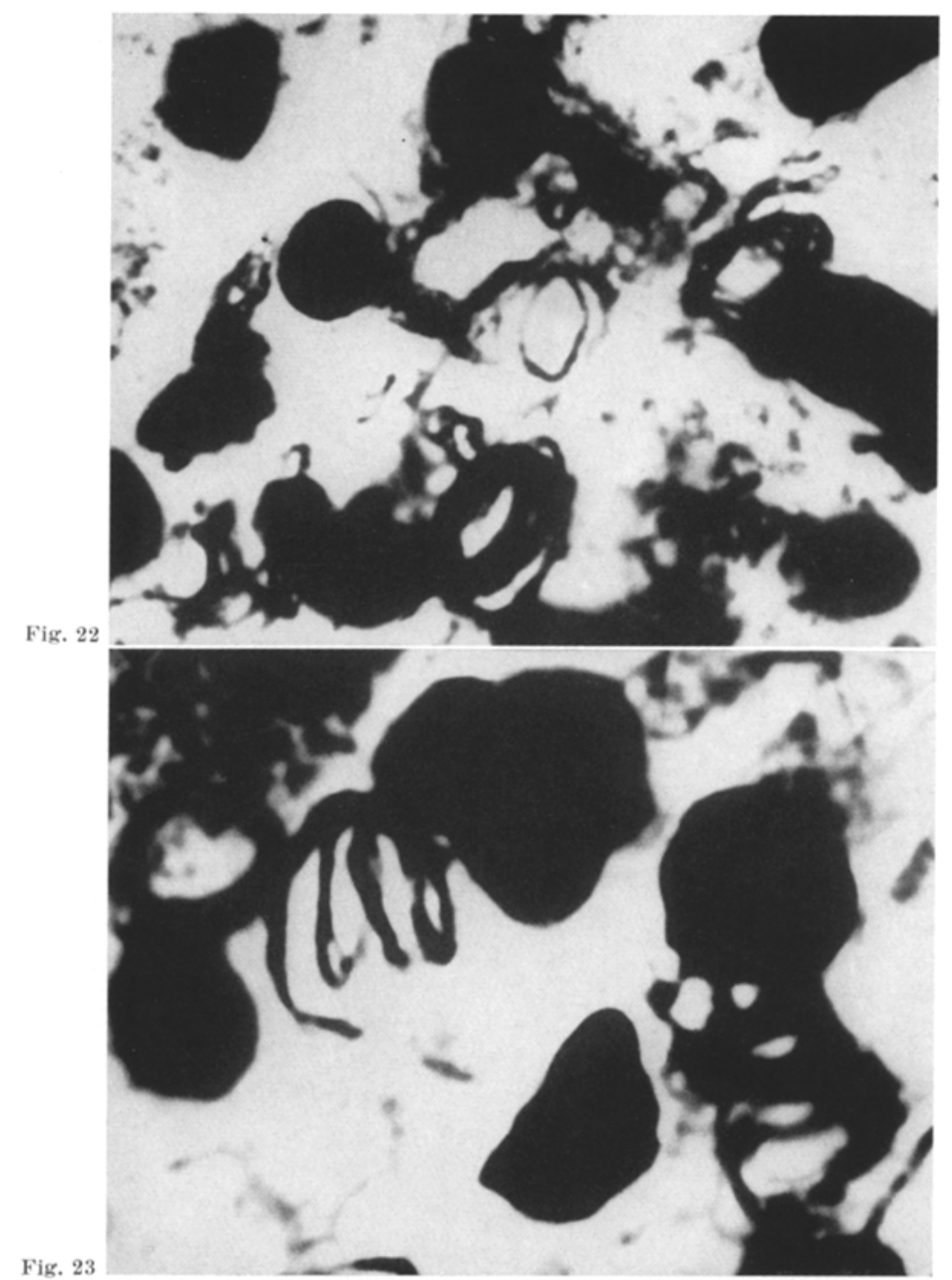

Fig. 22. Spirocytes of a "transitional or mixed" type of HoRTEGA with very thick ringlike coils. $\times 2000$

Fig. 23. Spirocytes with a large round body and large strong process with several coils. $\times 2000$

axon or dendrite, but not on it, which is typical of type III; it differs from type IV (elements of ScHWANN) which are characterized by a large nucleus placed on the nerve fibers and by a more elaborate structure which is spread over the entire length of the nerve, while the spirocytes are restricted to the proximal segments of axons and dendrites. In the spinal and in the gasserian ganglia the proximal segments of the axons and dendrites are supported by still another variety of 
spirocytes, the "riding glia" (Hontega, Pollak and Prado, Scharenberg, OrTIz-Pikon). This latter variety represents a transitional type of spirocyte, assigned to a very definite segment of the dendrite and axon and is, possiblys

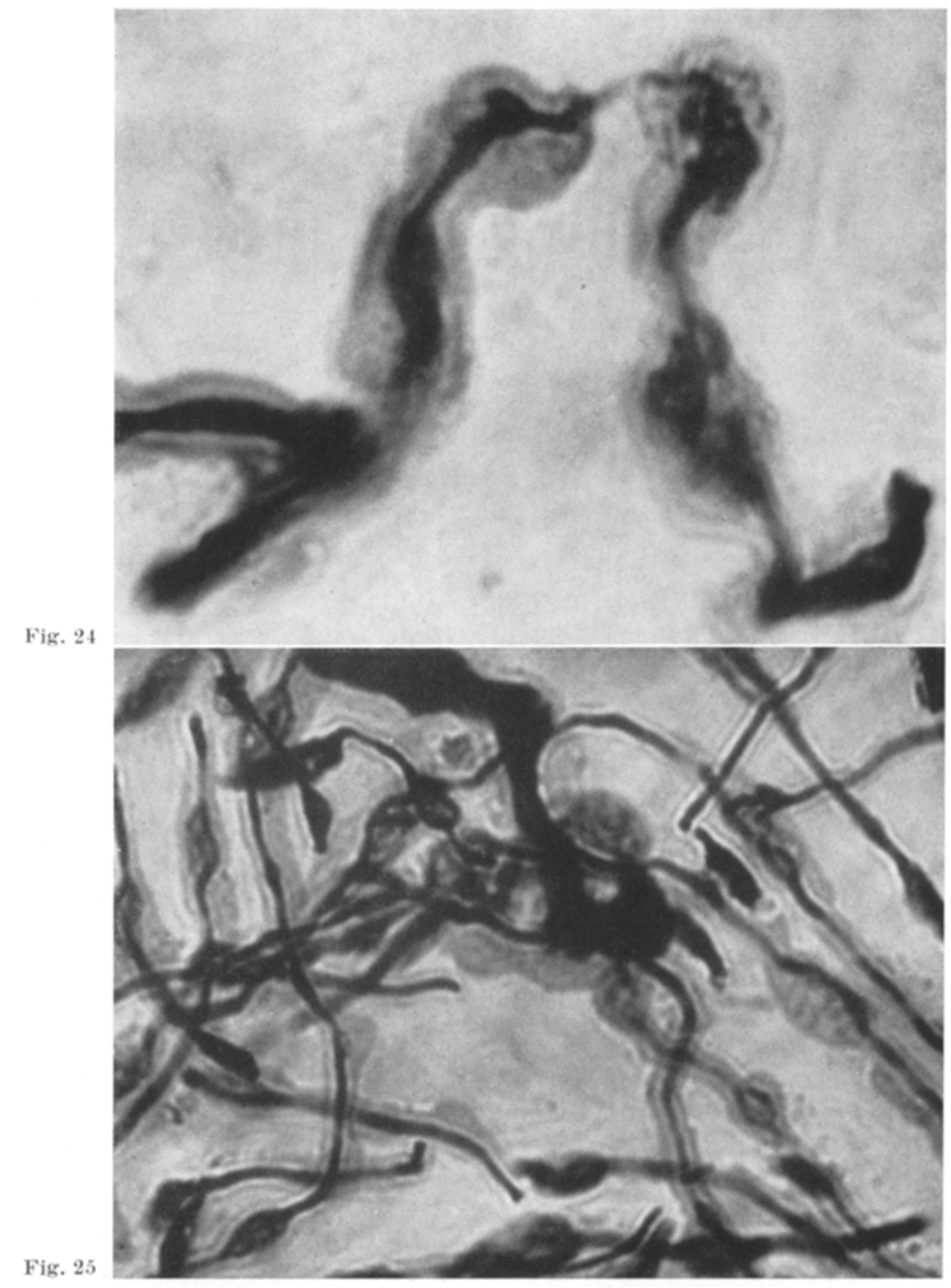

Fig. 24. All processes of the neuron including a terminal bouton are surrounded by a homogeneous plasmatic coating. $\times 2000$. (Ganglion Gasseri)

Fig. 25. Two receptors surrounded by a plasmatic coating and connected by a plasmatic bridge. Ganglion Gasseri (ScharenBerg 1952)

homologous with the mixed type of spirocytes of the sympathetic chain. The riding glia unquestionably also represents a variety of oligodendroglia.

The classification of various perisomatic gliocytes is more difficult. HoRTEGA and Prado homologized some of these cells with astrocytes, which some of them 
resemble. It is reasonable to assume that elements with gently arched or dichotomized processes and some of the multipolar types and, possibly, the "handle cells" represent astrocytes modified to requirements, but the nature of some other perisomatic elements such as those with a single coiled process connected with the pericaryon of the neuron and without visible connections with its processes (Fig. 12), and finally the nature of the laminar cells remains in doubt.

Some of the findings of HorTEga as well as those here described suggest that the spirocytes are not in direct contact with the processes of the neurons and that there is an "empty space" between the glia and the nerve fibers. In the sympathetic chain, so far, I have not been able to ascertain the histologic structure of this "empty space", nor did HorTega. However, in the gasserian ganglion it was possible to demonstrate a homogeneous plasmatic body which covers all processes of the neurons including the receptors, the paraphytes and the end bulbs (SCHARENBERG) (Fig. 24, 25, 26). This plasmatic substance stained a deli-

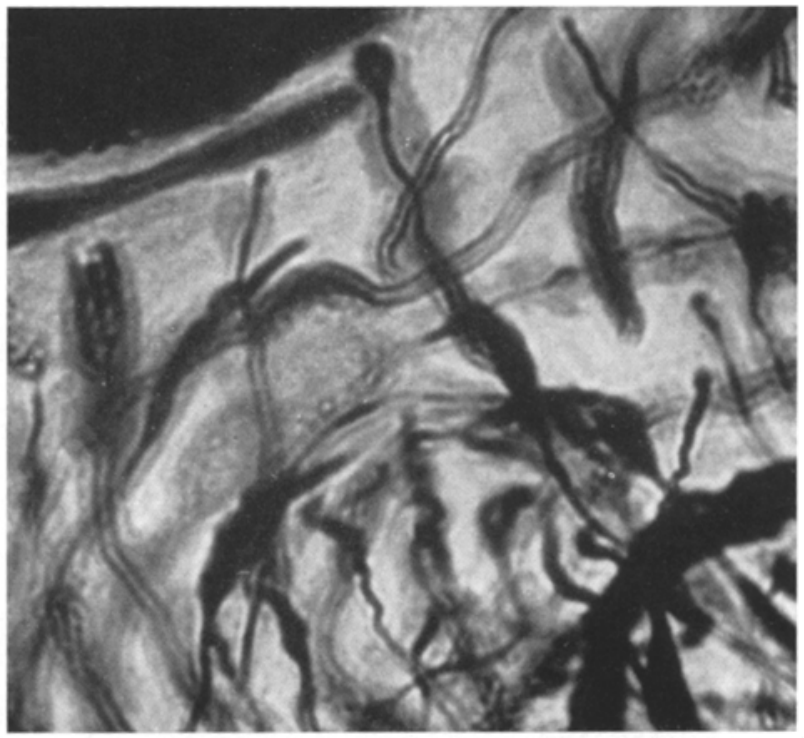

Fig. 26. Numerous paraphytes surrounded by a plasmatic coating. $\times 2000$ cate pink with the un-

reduced varient of the silver carbonate technique. This finding suggests that the coils of the spirocytes are separated from the dendrites by a plasmatic coating which obviously represents modified elements of ScHWANN and serves as a connecting medium between the spirocytes and the dendrites.

The recent advance of the knowledge of the relationship of the neurons and their satellite glia in the peripheral nervous system suggests that the nerve cell and its auxiliary elements represent a closely linked functional entity interconnected by a system of synapses.

There are mainly four types of synapse of interest here: 1. The axosomatic, 2. the axodendritic, 3 . the gliodendritic, and 4. the glio-dendro-somatic. The first two were described by CAJal in the nucleus cochlearis, the medulla and the spinal cord of the cat and the dog, and by ScHarenberg in the nucleus dentatus of man. The gliodendritic synapse was found by DE CASTRo, who was able to show that the preganglionic fibers in the plexus of AUERBacH connect with the cytoplasm of the gliocytes. The glio-dendro-somatic type is described here. These four types are common in the sympathetic, the gasserian and the spinal ganglia, but there are also others to be mentioned. 


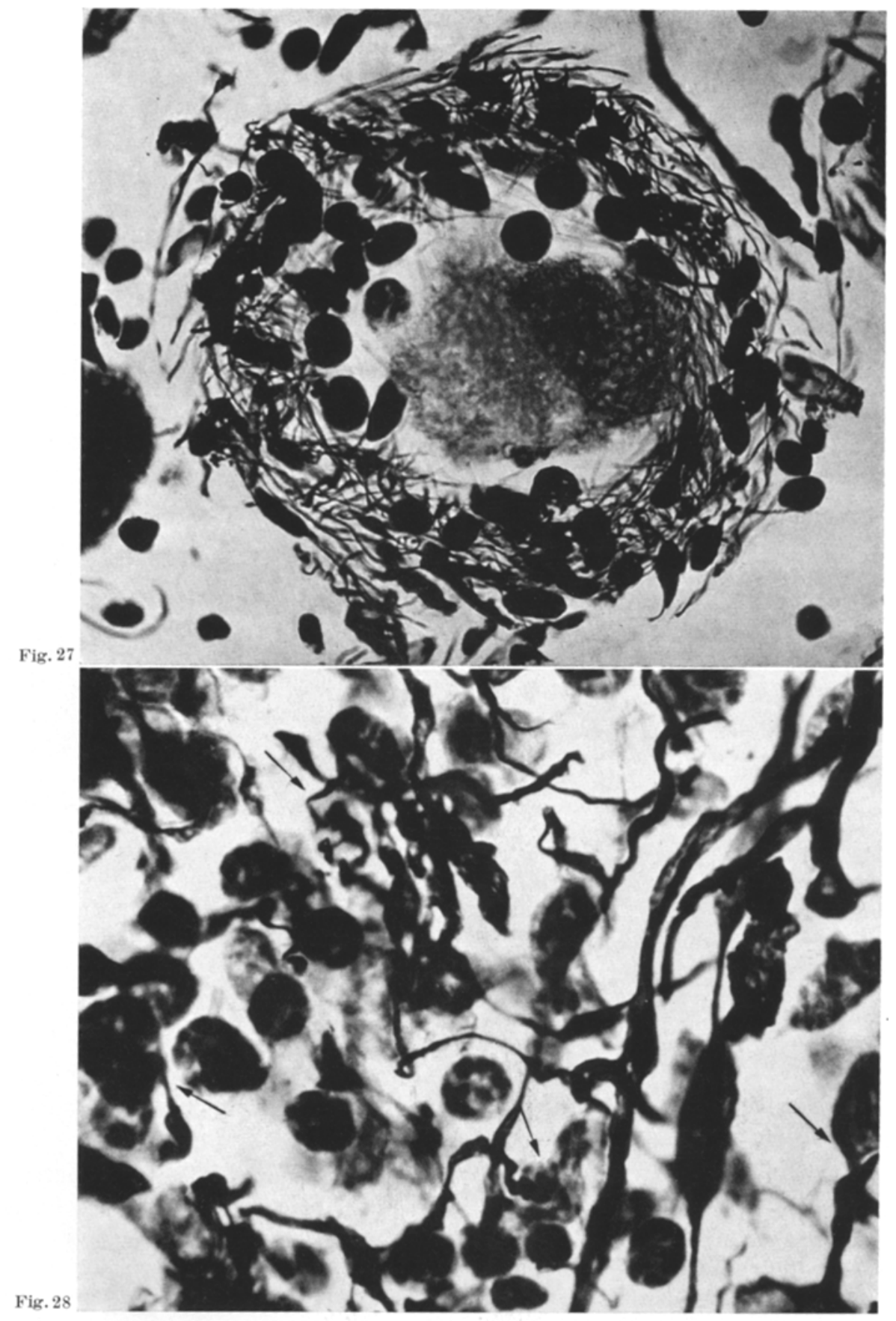

Fig. 27. Skeins of a neuron of the gasserian ganglion with numerous perisomatic cells. $\times 2000$ 
There are numerous gliosomatic connections between the perisomatic cells and the neurons in the spinal, sympathetic and gasserian ganglion:

1. Synapse between the gliocytes and the skeins (Fig. 27).

2 . Between the dendrites and the nuclei of the glia (Fig. 28).

3. In the gasserian ganglion Soharenberg demonstrated continuous connec. tions between the perisomatic glia and the structures of the pericaryon (Fig. 29).

4. Glio-dendro-somatic synapse connects the spirocytes with the dendrites and the pericaryon of the neuron; it is of particular interest since it consists of two closely linked, but distinctly different component parts: a) the synapse between the coils of the spirocytes and the dendri tes-the glio-dendritic connections and, b) the synapse between the central or ascending process of the spirocyte and the pericaryon of the neuron-the gliosomatic connection (Fig. 12 and 14).

The morphology of the synapse between numerous perisomatic elements in the sympathetic ganglia, such as the coiled cells, the "handle cells", the mono and multipolar gliocytes and finally the marginal elements remains obscure. There isreason to assume that the relationship of these elements and the pericaryon is very close, especially of the marginal glia which covers the pericaryon with a

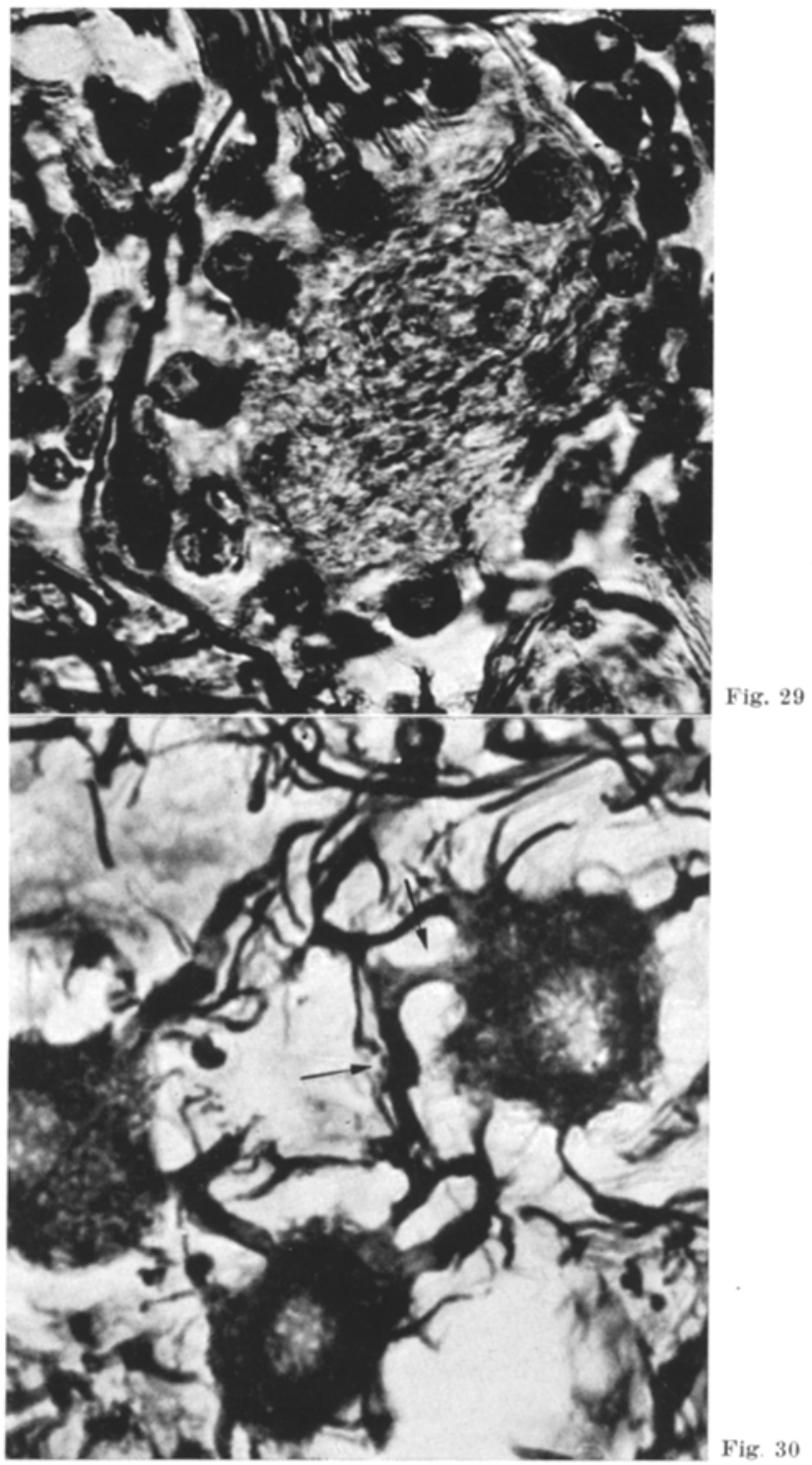

Fig. 29. Glio-somatic synapse; ganglion Gasseri $\times 2000$ (SCHARENBERG 1953)

Fig. 30. Direct dendro-somatic connection between two neurons; sympathetic ganglion. $\times 2000$ plasmatic reticulum.

Finally there should be mentioned a direct dendrosomatic connection between neighboring neurons, which is very distinct in the sympathetic ganglion; in this type of synapse a dendrite of the neuron enters without interruption into pericaryon of another cell (Fig. 30). 


\section{Zusammenfassung}

DeL Rio Hortega teilte die Glia der sympathischen und spinalen Ganglien in 2 Gruppen ein: 1. die perisomatische Glia, welche das Perikaryon der Parenchymzellen mit 2 übereinandergelagerten Schichten umgibt und 2. periaxonale Glia (Spirocyten), welche die Fortsätze der Ganglienzellen versorgt.

Die obere Schicht des perisomatischen Netzes besteht aus mono-, bi-, und multipolaren Elementen (Abb. 1-7), ,Henkelzellen“ (Abb. 8-11) and Gliocyten mit einem stark gebogenen, spiraligen Fortsatz (Abb. 12). Die untere, dem Perikaryon anliegende perisomatische Schicht besteht aus bizarr geformten, reticulären oder marginalen Elementen mit einem lappenartigen „reticulären“ (HorTeGA) Cytoplasma mit zahlreichen Vacuolen (Abb. 13-15).

Die periaxonale Glia (Spirocyten) umgibt die Fortsätze der Parenchymzellen mit zahlreichen Spiralen. Unter diesen Elementen lassen sich 4 Typen unterscheiden: 1. Spirocyten mit weiten Spiralen, 2. solche mit eng gegliederten Spiralen, 3. mit verflochtenen Fortsätzen, und 4. Übergangsformen (Abb. 16-23).

Die Elemente beider geschilderter Gruppen sind gliöser Natur. Für ihre Klassifizierung gelten die gleichen Grundsätze, wie für die Glia überhaupt.

Del Rio Hortega, Scharenberg und Ortez-Picon homologisieren die Spirocyten mit der Oligodendroglia vom Typ 3 (Palladino-Hortega), da der Körper der Spirocyten nicht auf dem Dendriten, sondern seitwärts von demselben gelagert ist, was auf den Abb. 16 und 18 deutlich zu sehen ist. Die Spirocyten sind auf die proximalen, von der bindegewebigen Kapsel umschlossenen Segmente der Dendriten beschränkt.

Die Übergangsformen der Spirocyten der sympathischen Ganglien und die „reitende" Glia der spinalen Ganglien (Hortega, Prado-Polak, Ortiz Picon) und die des Gasserschen Ganglions (ScharenberG) dürfen ebenfalls als Abarten der Oligodendroglia vom Typ 3 betrachtet werden.

Die Klassifizierung der perisomatischen Glia ist schwieriger als die der Spirocyten. Elemente von mono-, bi-, und pluripolarem Typ stellen wahrscheinlich modifizierte Astrocyten dar. Dagegen erscheint die Natur der ,laminären" oder „,reticulären“ sowie die der „Henkelzellen“" und der Elemente mit einem kurzen, stark gebogenen Fortsatz ungeklärt.

Wie die Befunde im Ganglion Gasseri beweisen, sind die Spiralen der Spirocyten von den Dendriten durch einen homogenen plasmatischen Körper getrennt (Abb. 24), desgleichen auch die terminalen Schwellungen, die Receptoren sowie die feinsten Fortsätze der Parenchymzellen (Abb. 25, 26).

Die Ganglienzellen und ihre Satelliten sind durch zahlreiche Synapsen verschiedener Typen zu einer funktionellen Einheit verbunden. Es lassen sich dabei mehrere Haupttypen von Synapsen unterscheiden:

1. Glio-somatische Synapsen zwischen perisomatischen Elementen und den Korbfasern (Abb. 27) sowie zwischen Dendriten und Gliazellen (Abb. 28).

2. Im Ganglion Gasseri bestehen direkte Verbindungen zwischen perisomatischen Zellen und den Strukturen des Perikaryon (Abb. 29).

3. Glio-dendro-somatische Synapsen zwischen den Spirocyten, den Dendriten und dem Perikaryon des Neurons. Dieser letzte Typ ist von besonderem Interesse, weil er aus 2 Komponenten besteht: a) der Synapse zwischen den Spiralen der Spirocyten und den Dendriten - die glio-dendritische Komponente und 
b) der Synapse, welche durch den zentralen Fortsatz der Spirocyten mit dem Perikaryon gebildet wird, die glio-somatische Komponente.

4. Dendro-somatische Synapse zwischen 2 Nervenzellen im sympathischen Ganglion (Abb. 30).

Die Morphologie der Synapsen zwischen einer Reihe von perisomatischen Zellen, wie der „Henkelzellen“, der mono- und pluripolaren Zellen und der ,,marginalen oder reticulären Gliocyten", ist noch ungeklärt.

\section{References}

CAJAL, S. R.: Les preuves objectives de l'unité anatomique des cellules nerveuses. Trab. Lab. Invest. Biol. 29, 1-137 (1934). - DE CASTRo, F.: Die normale Histologie des peripheren vegetativen Nervensystems. Verh. der Dtsch. Ges. für Pathologie, 34. Tagg in Wiesbaden vom 20.-23. April 1950. - Del Rio Hortega, P., M. Polak y J. M. Prado: Investigaciones sobre la neuroglia de los ganglios sensitivos. Arch. Histol. (B. Aires) 1, 233-274 (1942). Del Rto Hortega, P., Y J. M. Prado: Investigaciones sobre la neuroglia de los ganglios sympaticos. Arch. Histol. (B. Aires) 1, 83-136 (1942). - Ortiz Pikon, T. G.: The neuroglia of the sensory ganglia. Anat. Rec. 121, 513-529 (1955). - Scharenrerg, K. : Glia and the elements of Schwann of the human gasserian ganglion. Trab. Inst. Cajal Invest. biol. 44, 75-94 (1952). - Die Struktur der Synapsen im Nucleus Dentatus des Menschen. Z. Zellforsch. 51, 50-55 (1959).

Dr. K. Scharenbere, Laboratory of Neuropathology, Department of Psychiatry, University of Michigan Medical Center, Ann Arbor, Michigan (USA) 